\title{
HUBUNGAN ANTARA ASUPAN ENERGI DAN AKTIVITAS FISIK DENGAN PERSEN LEMAK TUBUH PADA WANITA PESERTA SENAM AEROBIK
}

\author{
Irma Nur Amelia, Ahmad Syauqy ${ }^{*}$ \\ Program Studi Ilmu Gizi Fakultas Kedokteran Universitas Diponegoro \\ Jl.Dr.Sutomo No.18, Semarang, Telp (024) 8453708, Email : gizifk@undip.ac.id
}

\begin{abstract}
Background : Excessive body fat may increase the risk of various diseases. Accumulation of body fat may occur as the result of energy imbalance such as excessive energy intake and lack of physical activity that occurs in the long term. Physical activity can be improved with exercise. Aerobic is one of exercises that can reduce body fat. This study aimed to analyze the association between energy intake and physical activity with body fat percentage in women aerobic dance participants

Method : Observational research with cross sectional design was conducted in Sanggar Senam St.Anna Semarang. The sample were 60 women aerobic dance participants aged 20-40 years that was selected using consecutive sampling method. Body fat percentage was measured by Bioelectrical Impedance Analysis (BIA). Energy intake and physical activity were obtained with interview using semiquantitative Food Frequency Questionnaire (FFQ) and $2 \times 24$ hours physical activity recall. Data was analyzed using person correlation test.

Result : Energy intake was positively correlated with body fat percentage $(r=0,228 ; p=0,080)$ while physical activity was negatively correlated with body fat percentage $(r=-0,357 ; p=0,005)$. Multivariate test in this study showed that physical activity associated with body fat percentage $\left(R^{2}=12,8 \%\right.$ dan $\left.p=0,005\right)$.

Conclusion : Energy intake was positively correlated with body fat percentage, while physical activity was negatively correlated with body fat percentage.

Keyword: Energy intake, physical activity, body fat percentage, aerobic dance
\end{abstract}

\begin{abstract}
ABSTRAK
Latar Belakang : Lemak tubuh yang melebihi batas normal dapat meningkatkan risiko berbagai macam penyakit. Penumpukan lemak tubuh dapat terjadi akibat adanya ketidakseimbangan energi yaitu asupan energi berlebih dan aktivitas fisik kurang yang terjadi dalam jangka waktu lama. Aktivitas fisik dapat ditingkatkan dengan melakukan olahraga. Senam aerobik merupakan salah satu jenis olahraga yang dapat menurunkan lemak tubuh. Penelitian bertujuan untuk mengetahui hubungan antara asupan energi dan aktivitas fisik dengan persen lemak tubuh wanita peserta senam aerobik.

Metode : Penelitian observasional dengan rancangan cross-sectional bertempat di Sanggar Senam St.Anna Kota Semarang. Sampel berjumlah 60 subjek yang merupakan wanita peserta senam aerobik usia 20-40 tahun dan dipilih menggunakan metode consecutive sampling. Persen lemak tubuh diukur menggunakan Bioelectrical Impedence Analysis (BIA). Asupan energi dan aktivitas fisik diperoleh dengan wawancara menggunakan FFQ semi kuantitatif dan recall aktivitas fisik $2 \times 24$ jam. Data dianalisis menggunakan uji korelasi pearson dan uji regresi linier ganda.

Hasil : Asupan energi berkorelasi positif bermakna dengan persen lemak tubuh $(r=0,228 ; p=0,080)$ sedangkan aktivitas fisik berkorelasi negatif bermakan dengan persen lemak tubuh $(r=-0,357 ; p=0,005)$. Uji multivariat pada penelitian ini menunjukkan bahwa aktivitas fisik yang paling berhubungan dengan persen lemak tubuh $\left(R^{2}=\right.$ $12,8 \%$ dan $p=0,005)$.
\end{abstract}

Simpulan : Asupan energi berkorelasi positif tidak bermakna dengan persen lemak tubuh sedangkan aktivitas fisik berkorelasi negatif bermakna dengan persen lemak tubuh.

Kata kunci : asupan energi, aktivitas fisik, persen lemak tubuh, senam aerobik

\section{PENDAHULUAN}

Prevalensi

obesitas

mengalami peningkatan dan menjadi permasalahan kesehatan diberbagai negara maju dan berkembang. Obesitas merupakan suatu kondisi akumulasi massa lemak tubuh yang melebihi batas normal. Pada kondisi normal rata-rata jumlah lemak tubuh orang dewasa berkisar antara $10 \%$ - $25 \%$ pada pria dan $18 \%$ $30 \%$ pada wanita. ${ }^{1}$ Kelebihan lemak tubuh dapat meningkatkan risiko penyakit kardiovaskuler, diabetes melitus tipe 2 dan beberapa jenis kanker. ${ }^{2}$ Data statistik WHO (World Health Organization) menunjukkan sebanyak 2,8 juta penduduk dunia mengalami kematian yang diakibatkan obesitas. ${ }^{3}$

Kelebihan lemak tubuh dapat terjadi akibat adanya ketidakseimbangan energi dalam tubuh yaitu asupan energi yang lebih besar dibanding dengan energy expenditure (keluaran energi) 
dalam jangka waktu lama. ${ }^{4}$ Energi merupakan hasil metabolisme karbohidrat, protein dan lemak yang terkandung dalam makanan yang diasup seseorang. Energi yang berlebihan dalam tubuh akan diubah menjadi trigliserida dan akan disimpan dijaringan adiposa sebagai lemak tubuh. ${ }^{2}$ Penelitian di Amerika menunjukkan bahwa peningkatan ratarata asupan energi sebesar $341 \mathrm{kkal} / \mathrm{hari}$ berdampak pada peningkatan prevalensi obesitas pada wanita dari $16,6 \%$ menjadi $36,5 \%{ }^{5}$

Asupan energi berlebih yang disertai dengan aktivitas fisik yang kurang dapat menjadi penyebab terjadinya penumpukan lemak tubuh. Penelitian di Amerika menunjukan bahwa 50\% individu dengan tingkat aktivitas fisik rendah mempunyai risiko lebih besar dalam peningkatan simpanan lemak tubuh dibandingkan individu dengan aktivitas fisik tinggi. ${ }^{6}$ Aktivitas fisik dapat meningkatkan oksidasi lemak tubuh sehingga dapat menurunkan simpanan lemak tubuh di jaringan adiposa. $^{7} \quad$ Aktivitas fisik dapat ditingkatkan dengan melakukan olahraga secara teratur. Salah satu jenis olahraga yang dapat menurunkan lemak tubuh dan dapat dijadikan intervensi nonpharmacological dalam menanggulangi masalah kelebihan lemak tubuh adalah senam aerobik. ${ }^{8}$

Penelitian di Turki yang dilakukan pada wanita obesitas yang diberi intervensi senam aerobik selama 8 minggu dengan intensitas 3 kali per minggu dan durasi 60 menit menunjukkan adanya penurunan lemak tubuh rata-rata sebesar $3,5 \%$. Penelitian lain yang dilakukan di Iran pada wanita inactiv selama 12 minggu dengan intensitas 3 kali per minggu dan durai 60 menit menunjukkan bahwa ada perubahan yang signifikan terhadap persen lemak tubuh rata-rata sebesar $2,3 \%{ }^{10}$

Saat ini banyak tempat latihan fisik yang menawarkan program penurunan lemak tubuh, salah satunya ialah senam aerobik. Jenis latihan fisik tersebut banyak diminati dan diikuti masyarakat khususnya oleh kaum wanita, tetapi masih terdapat peserta senam aerobik yang belum dapat mencapai penurunan lemak tubuh yang diharapkan. Menurut hasil penelitian yang dilakukan di salah satu tempat senam aerobik di Kota Semarang menunjukkan bahwa sebanyak $54,7 \%$ peserta mengalami overweight dan sebanyak $66,7 \%$ peserta mempunyai tingkat asupan energi berlebih. ${ }^{11}$

Penelitian ini bertujuan untuk mengetahui hubungan antara asupan energi dan aktivitas fisik dengan persen lemak tubuh pada wanita peserta senam aerobik.

\section{METODE}

Penelitian ini termasuk dalam ruang lingkup keilmuan gizi masyarakat yang dilakukan di Sanggar Senam St.Anna Kota Semarang pada bulan Agustus - September. Jenis penelitian ini adalah penelitian observasional yang dilakukan dengan rancangan cross-sectional.

Populasi penelitian ini adalah semua wanita peserta senam aerobik di Sanggar Senam St.Anna. Jumlah sampel minimal pada penelitian ini adalah 56 subjek. Pengambilan sampel dilakukan dengan menggunakan metode consecutive sampling dengan kriteria inklusi yaitu peserta senam aerobik berumur 20-40 tahun, telah aktif mengikuti senam aerobik minimal $\geq 3$ bulan dan tidak mengonsumsi obat penurun lemak tubuh.

Variabel bebas pada penelitian ini adalah asupan energi dan aktivitas fisik. Variabel terikat adalah persen lemak tubuh. Asupan energi merupakan hasil konsumsi energi yang berasal dari zat gizi makro (karbohidrat, lemak dan protein) yang terdapat dalam makanan dan minuman. Diperoleh dari wawancara langsung menggunakan formulir Food Frequency Questionnaire (FFQ) semi kuantitatif dengan hasil ukur dalam satuan kkal. Aktivitas fisik adalah hasil penilaian rerata besarnya energi yang dikeluarkan subjek selama 24 jam. Penilaian diperoleh melalui wawancara langsung menggunakan formulir recall aktivitas fisik $2 \times 24$ jam, aktivitas fisik yang dihitung ialah semua aktivitas fisik yang dilakukan subjek pada hari kerja dan hari libur termasuk senam aerobik. Energi yang dikeluarkan untuk beraktivitas selama 24 jam dihitung dengan cara mengkalikan metabolisme basal setiap kegitan (kkal) dengan lamanya kegitan tersebut dilakukan. Hasil ukur dinyatakan dalam satuan kkal. Persen lemak tubuh adalah jumlah simpanan lemak tubuh yan diukur menggunakan Bioelektrical Impedence Analysis (BIA) dengan membandingkan total lemak tubuh dengan berat badan dan hasil ukur dinyatakan dalam persentase (\%).

Pengambilan sampel diawali dengan melakukan pengumpulan data yang meliputi identitas sampel, pengukuran tinggi badan, berat badan dan persen lemak tubuh. Pengukuran tinggi badan menggunakan microtoise dengan ketelitian $0,1 \mathrm{~cm}$. Berat badan dan persen lemak tubuh diukur menggunakan Bioelectrical Impedence Analysis (BIA) dengan ketelitian 0,1 kg. Asupan energi dan aktivitas fisik diperoleh dengan wawancara langsung menggunakan FFQ semi kuantitatif dan recall aktivitas fisik 2x24 jam. 
Pengolahan dan analisis data dilakukan dengan program komputer. Analisis univariat digunakan untuk menggambarkan karakteristik subjek dan mendeskripsikan masing-masing variabel. Analisis bivariat digunakan untuk mengetahui hubungan antara variable bebas dan terikat dengan uji korelasi Person yang sebelumnya dilakukan uji normalitas data dengan uji Kolmogorov-Smirnov. ${ }^{13}$ Analisis multivariat digunakan untuk memprediksi variabel yang paling berpengaruh terhadap persen lemak tubuh dengan uji linier ganda.

\section{HASIL PENELITIAN}

Jumlah sampel yang terlibat dalam penelitian ini sebanyak 60 subjek.

Tabel 1. Distribusi asupan energi, aktivitas fisik dan persen lemak tubuh peserta senam aerobik

\begin{tabular}{lccc}
\hline Variabel & Minimum & Maksimum & rerata \pm SD \\
\hline Asupan energi (kkal) & 1810,9 & 2647,5 & $2126,00 \pm 171,10$ \\
Aktifitas fisik (kkal) & 1933 & 2465 & $2220,83 \pm 134,38$ \\
Frekuensi senam (kali/minggu) & 2 & 6 & $2,87 \pm 0,965$ \\
Lemak tubuh (\%) & 22,2 & 38 & $30,13 \pm 4,23$ \\
\hline
\end{tabular}

Tabel 1 menunjukkan rerata asupan energi, aktivitas fisik dan persen lemak tubuh, subjek berturut-turut sebesar 2126,00 $\pm 171,10$ kkal, $2220,83 \pm 134,38 \mathrm{kkal}$ dan $30,13 \pm 4,23 \%$.

\section{Hubungan Asupan Energi dan Aktivitas Fisik dengan Persen Lemak Tubuh}

Hubungan asupan energi dan aktivitas fisik dengan persen lemak tubuh dapat dilihat pada tabel 2.

Tabel 2. Hubungan asupan energi dan aktivitas fisik dengan persen lemak tubuh

\begin{tabular}{|c|c|c|c|}
\hline & \multicolumn{3}{|c|}{ Persen lemak tubuh } \\
\hline & $\mathbf{n}$ & $\mathbf{r}$ & $p$ \\
\hline Asupan Energi & 60 & 0,228 & 0,080 \\
\hline Aktivitas Fisik & 60 & $-0,357$ & 0,005 \\
\hline
\end{tabular}

\section{* Uji korelasi pearson}

Berdasarkan hasil analisis data asupan energi dan persen lemak tubuh didapatkan nilai $r=0,228$ dan $p=0,080$ yang menunjukkan adanya arah korelasi positif dengan kekuatan yang lemah antara asupan energi dengan persen lemak tubuh, tetapi tidak ada hubungan yang signifikan antara asupan energi dengan persen lemak tubuh. Korelasi positif mengartikan bahwa semakin tinggi asupan energi maka persen lemak tubuh akan semakin tinggi.

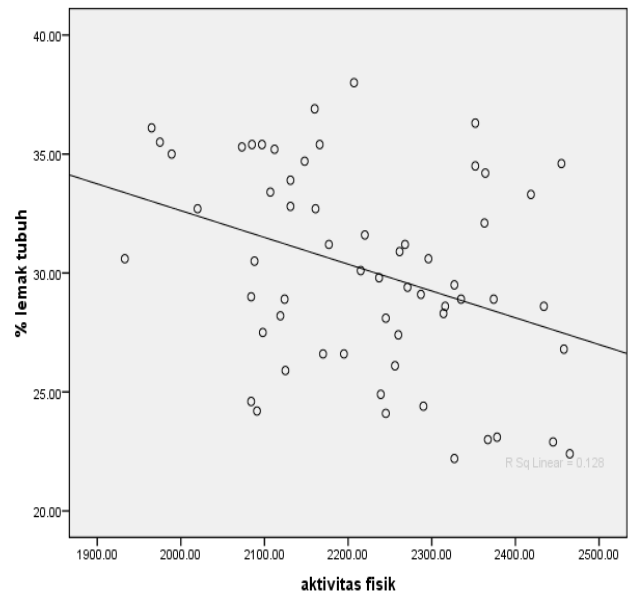

Gambar 2. Hubungan aktivitas fisik dengan
Hasil analisis data aktivitas fisik dan persen lemak tubuh didapatkan nilai $\mathrm{r}=-0,357$ dan $p=0,005$ yang menunjukkan adanya korelasi negatif dengan kekuatan yang lemah antara aktivitas fisik dengan persen lemak tubuh dan secara signifikan terdapat hubungan antara aktivitas fisik dengan persen lemak tubuh. Korelasi negatif mempunyai arti semakin tinggi aktivitas fisik maka persen lemak tubuh semakin rendah.

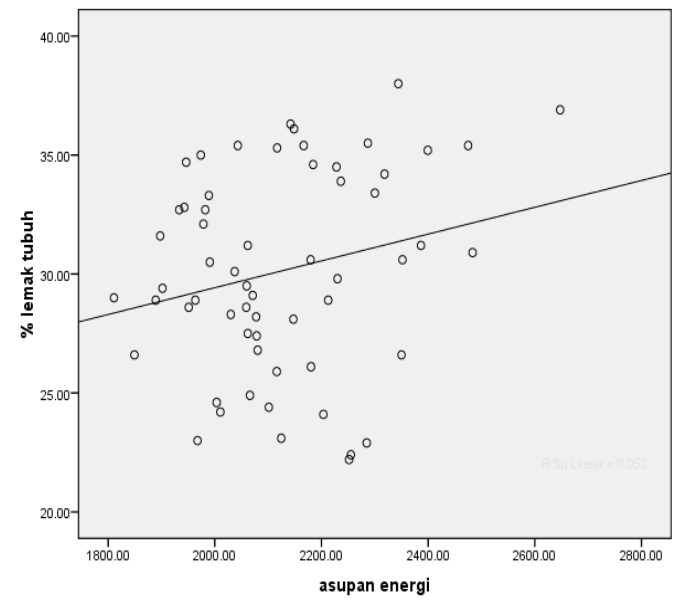

Gambar 1. Hubungan asupan energi dengan persen lemak tubuh 
Tabel 3. Hasil uji multivariat

\begin{tabular}{llrll}
\hline Variabel & B & Beta & $\boldsymbol{p}$ & Persamaan garis \\
\hline (constan) & 55,135 & & & persen lemak tubuh $=55,135-0,011$ (aktivitas \\
Asupan & 0,005 & 0,217 & 0,07 & fisik) \\
energi & $-0,011$ & $-0,357$ & 7 & \\
Aktivitas & & & 0,00 & \\
fisik & & & 5 & \\
\hline
\end{tabular}

Hasil uji multivariat menunjukan variabel yang berhubungan dengan persen lemak tubuh adalah aktivitas fisik dengan $\mathrm{p}=0,005, \mathrm{R}^{2}=0,128$ $(12,8 \%$ variasi persen lemak tubuh ditentukan oleh aktivitas fisik dan sisanya dipengaruhi oleh variabel lain). Pada tabel 3 menunjukan persamaan garis yang berarti bahwa setiap pengeluaran $1 \mathrm{kkal}$ energi dari aktivitas fisik maka akan mengurangi persen lemak tubuh sebesar 0,011

\section{PEMBAHASAN}

Pada penelitian ini menunjukkan adanya korelasi positif antara asupan energi dengan persen lemak tubuh, tetapi tidak terdapat hubungan yang bermakna antara asupan energi dan persen lemak tubuh pada wanita peserta senam aerobik $(\mathrm{r}=$ 0,228 dan $p=0,080$ ). Korelasi positif mempunyai arti bahwa semakin tinggi asupan energi maka semakin tinggi persen lemak tubuh seseorang. Hal ini sejalan dengan teori yang menyatakan bahwa asupan energi yang melebihi kebutuhan akan disimpan sebagai cadangan energi dalam bentuk lemak tubuh. ${ }^{2}$

Energi merupakan hasil metabolisme karbohidrat, protein dan lemak yang terkandung dalam makanan yang diasup seseorang. Setiap zat gizi menyumbangkan energi yang berbeda. Lemak mempunyai energi yang besar yaitu 9 kkal dibandingkan karbohidrat dan protein yang masing-masing mempunyai energi sebesar $4 \mathrm{kkal}$. Kelebihan asupan lemak akan disimpan tubuh dalam bentuk trigliserida di jaringan adiposa. Karbohidrat disimpan dalam bentuk glikogen dalam hati dan otot, sedangkan protein akan disimpan sebagai protein tubuh. Penyimpanan karbohidrat dan protein memiliki tempat yang terbatas sehingga apabila terjadi kelebihan glukosa dan asam amino dalam tubuh akan diubah dengan cepat menjadi asam lemak dan diubah menjadi trigliserida yang akan disimpan di jaringan adiposa. Energi yang berlebihan dari hasil metabolirme zat gizi makro akan disimpan dijaringan adiposa sebagai lemak tubuh., ${ }^{2,20}$ Penelitian yang dilakukan di Norwegia menunjukkan terdapat hubungan positif antara asupan protein dengan persen lemak tubuh. ${ }^{12} \mathrm{Hal}$ ini menunjukkan bahwa apabila asupan protein tinggi maka akan berdampak pada tingginya persen lemak tubuh. Penelitian di Amerika menunjukkan bahwa peningkatan rata-rata asupan energi sebesar 341 kkal sehari berdampak pada peningkatan prevalensi obesitas pada wanita dari $16,6 \%$ menjadi $36,5 \% .^{5}$

Pada penelitian ini menunjukkan adanya korelasi negatif antara aktivitas fisik dengan persen lemak tubuh dan terdapat hubungan yang bermakna antara aktivitas fisik dengan persen lemak tubuh $(\mathrm{r}=-0,357$ dan $p=0,005)$. Hal ini menunjukkan bahwa semakin tinggi aktivitas fisik seseorang maka persen lemak tubuh akan semakin rendah. Hasil penelitian ini sejalan dengan teori yang menyatakan bahwa semakin tinggi pengeluaran energi melalui aktivitas fisik maka persen lemak tubuh akan semakin rendah. Melakukan aktivitas fisik akan meningkatkan metabolisme dan menyebabkan penggunaan cadangan energi yang berupa lemak tubuh dapat terbakar dan digunakan sebagai energi. Aktivitas fisik merupakan pergerakan dari sistem muskuloskeletal yang menghasilkan pengeluaran energi. Pergerakan otot pada saat melakukan aktivitas fisik menyebabkan terjadinya pemecahan trigliserida pada jaringan adiposa menjadi asam lemak bebas yang akan diubah menjadi energi.

Aktivitas fisik dapat ditingkatkan dengan melakukan olahraga. Olahraga dapat meningkatkan pengeluaran energi yang tersimpan dalam tubuh dan meningkatkan oksidasi lemak tubuh. ${ }^{7}$ Subjek dalam penelitian ini melakukan jenis olahraga aerobik yaitu senam aerobik dengan intensitas minimal 2 kali dalam seminggu dengan durasi 60 menit. Kalori yang dikeluarkan dalam setiap melakukan senam aerobik rata-rata sebesar 480 kkl. ${ }^{14}$ Sumber energi yang digunakan pada saat melakukan senam aerobik tidak hanya berasal dari glikogen otot melainkan dari lemak yang tersimpan dalam tubuh. Hal ini dikarenakan senam aerobik merupakan olahraga dengan intensitas sedang yang dilakukan dengan durasi yang lama. Cadangan glikogen otot tubuh mempunyai simpanan yang sedikit, oleh karena itu simpanan lemak akan digunakan juga untuk sumber energi saat 
melakukan senam aerobik.,14 Penelitian di Turki yang dilakukan pada wanita obesitas yang diberi intervensi senam aerobik selama 8 minggu dengan intensitas 3 kali per minggu dan durasi 60 menit menunjukkan adanya penurunan lemak tubuh rata-

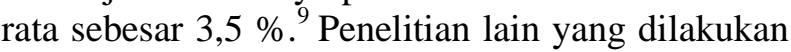
di Iran pada wanita inactiv selama 12 minggu dengan intensitas 3 kali per minggu dan durai 60 menit menunjukkan bahwa ada perubahan yang signifikan terhadap persen lemak tubuh rata-rata sebesar $2,3 \% .^{10}$ Subjek dalam penelitian ini sudah melakukan senam aerobik lebih dari 12 minggu, tetapi tidak diketahui berapa persen lemak tubuh sebelum mengikuti senam aerobik, sehingga tidak dapat diketahui berapa penurunan persen lemak tubuh setelah mengikuti senam aerobik.

Hasil uji multivariat menunjukan bahwa variabel yang paling berhubungan dengan persen lemak tubuh adalah aktivitas fisik dengan $\mathrm{R}^{2}=$ $12,8 \%$ dan $\mathrm{p}=0,005$. Pada penelitian ini $12,8 \%$ variasi persen lemak tubuh ditentukan oleh aktivitas fisik, sisanya dipengaruhi oleh variabel lain yang tidak dapat dikendalikan, kemungkinan variabel lain yaitu genetik dan hormonal.

Faktor genetik memberikan pengaruh terhadap bentuk, ukuran dan komposisi tubuh manusia. Disebutkan bahwa lemak tubuh seseorang dipengaruhi oleh faktor genetik sebesar $25 \%$. Pengaruh hormon dalam regulasi asupan makanan juga dapat berpengaruh terhadap persen lemak tubuh seperti hormon ghrelin, leptin dan insulin. ${ }^{2,20}$ Dalam penelitian ini kedua faktor tersebut tidak dapat dikendalikan sehingga tidak dapat dianalisis bagaimana pengaruhnya terhadap persen lemak tubuh subjek.

\section{SIMPULAN}

Asupan energi mempunyai korelasi positif tidak bermakna dengan persen lemak tubuh. Aktivitas fisik mempunyai korelasi negatif bermakna dengan persen lemak tubuh. Pada penelitian ini $12,8 \%$ variasi persen lemak tubuh ditentukan oleh aktivitas fisik.

\section{SARAN}

Bagi peserta senam aerobik diharapkan adanya pengontrolan asupan energi dan peningkatan aktivitas fisik sehari-hari agar terjadi keseimbangan energi, sehingga dapat meminimalkan terjadinya akumulasi lemak tubuh yang berlebih.

\section{UCAPAN TERIMAKASIH}

Puji syukur penulis panjatkan kepada Allah SWT atas limpahan rahmat-Nya. Penulis mengucapkan terimakasih kepada peserta dan pengurus Sanggar Senam St.Anna Semarang yang telah bekerja sama dan membantu terlaksananya penelitian ini.

\section{DAFTAR PUSTAKA}

1. Lysen LK, Israel DA. Nutrition in weight management. In : Mahan LK, Escott-Stump S, Raymond JL, editors. Krause's food and the nutrition care process. $13^{\text {th }}$ ed. Philadelphia : Saunder Elsevier, inc ; 2012. p. 463-464.

2. Thompson JL, Manore MM, Vaughan LA. The science of nutrition. 2nd ed. San Franscisso : Pearson Education, Inc; 2011. p. 486-489; 272273.

3. World Health Organization. World Health Statistics 2012.

4. Astrup A, Tremblay A. Energy Metabolism. In : Gibney MJ, Lanham-New SA, Cassidy A, Voster $\mathrm{HH}$, editors. Introduction to human nutrition. 2nd ed. United Kindom : The Nurtrition society ; 2009. p.31- 48

5. Austin GL, Ogden LG, Hill JO. Trend in carbohydrate, fat, and protein intakes and association with energy intake normal-weight, overweight, and obese indviduals : 1971-2006. Am J Clin Nutr 2011;93:836-43.

6. Kokkinos P, Myers J. Exercise and physical activity. Circulation 2010; 122: 1637-1648.

7. Thompson D, Karpe F, Lafontan M, Frayn K. Physical activity and exercise in the regulation of human adipose tissue physiology. Physiol Rev 2012; 92 : 157-191.

8. Thorogood A, Mottillo S, Shimony A, filion KB, Joseph L, Genest J, et al. Isolated aerobic exercise and weight loss: a systematic review and metaanalysis of randomized controlled trials. The Amrican Journal of Medicine 2011; 124: 747-755.

9. Cakmakci E, Arslan F, Taskin H, Cakmakci O. The effects of aerobic dance exercise on body composition changes associated with change in sedentary women. Selcuk University Journal of Phisical Education and Sport Science 2011; 13(3) : 289-304.

10. Ossanloo P, Najar L, Zafari A. The effects combined training (aerobic dance, step exercise and resistance training) on body fat percents and lipid prfile in sedentary females of Al Zahra University. European Journal of Experimental Biology 2012 ; 2(5) : 1598-1602.

11. Kartikaningrum WK. Hubungan praktik senam aerobik dengan penurunan berat badan pada wanita yang mengalami overweight (skripsi). Fakultas Kesehatan Masyarakat Universitas Dian Nuswantoro.2007. 
12. Vinknes KJ, Vogel SD, Elshorbagy AK, Nurk E, Drevon CA, Gjesdal CG, et al. Dietary intake of protein is positively associated with percent body fat in middle-aged and older adults. J Nutr 2011; 141: 440-446.

13. Dahlan M. Sopiyudin. Statistik untuk kedokteran dan kesehatan. Jakarta : Salemba Medika ; 2011.

14. Williams. Nutrition for health, fitness and sport. New York : McGraw-Hill,inc; 2007.

15. Gropper SS, Smith J, Groff JL. Advanced nutrition and human metabolism. $5^{\text {th }}$ ed. Canada : Wadswoth ; 2009 . 